\title{
Publishing and studying of a group of stirrups preserved in Gayer-Anderson Museum in Cairo as compared with models of paintings of Ottoman manuscripts
}

\section{Dr. Amin Abd Allah Rashaidy}

\section{Abstract:}

This study highlights a group of masterpieces which are known as "stirrups" preserved in Gayer-Anderson Museum in Cairo. The study has clarified their function of helping people in riding horses, and supporting the horsemen's back stability. The study also deals with the linguistic semantics of stirrups, in addition to the beginning of their historical appearance and development, especially in terms of the role of Muslims as represented in AlMuhallab Ibn Abi Sufra in making them out of iron. The study also focuses on the iron that was used as a raw material in making the stirrups, the method of industry, by casting in a mold, and the decorative methods of engraving and gilding. This paper also clarifies the types of vegetal decorations on the stirrups, such as bouquets of roses, leaves and fruits of pomegranates, and the types of the geometric motifs which are represented in triangles, circles and pearl's beads, and zigzag decorations. This research also highlights the history of stirrups from the $13^{\text {th }}$ century A.H. to the $19^{\text {th }}$ century A.D., especially that they did not carry inscriptions referring to their history. Thus, they were compared with the miniatures of manuscripts and applied masterpieces which carried the same decorations. This paper focuses on three unpublished masterpieces, including three figures done by the researcher. The study concluded six new results in the field of Islamic Arts.

\section{Keywords:}

Stirrups - horse - iron - casting in the mold - engraving - gilding - roses - pomegranates - triangles - painting.

- Associate Professor of Islamic Archaeology and Arts, Faculty of Archaeology - Fayoum University, aar01@fayoum.edu.eg 


\section{Linguistic semantics:}

The word stirrup derives from the verb "to ride" which means "to ascend." Its plural is "stirrups." The word "Stirrup" was given by Arabs to refer to "Camels." Stirrups refers to the riding of camels or carrying something for camels were intended to carry things on their back. ${ }^{(1)}$ It is the name of a group. ${ }^{(2)}$ In fact, the English word "stirrup" stems from old English stirap, stigrap, Middle English stirop, styrope, i.e. a mounting or climbing rope, And from old English stìgan which means "to ascend." ${ }^{(3)}$

\section{History of Stirrup}

The stirrup is one of the most important inventions in the history of warfare after both the chariot and the saddle ${ }^{(4)}$, as a tool allowing the expanded use of horses in warfare ${ }^{(5)}$, although horses were domesticated in approximately 4500 B.C. by the ancient Egyptians ${ }^{(6)}$. The earliest manifestation of the stirrup was

(1) Majmae Allugha Alarabia, Almoajam Alwasit, $1^{\text {st }}$ Part, Egypt, $2^{\text {nd }}$ Edition, Cairo, 2004, p. 368.

(2) Ibn Manzoor (Gamal Edin Abu Al Fadil Mohammed Ibn Makram 711 A.H./1371 A.D.), Lisan Al Arab, Vol. III, Dar Al Ma'arif, No date, Cairo, pp. 13-17.

(3) http://www.dictionary.com

(4)The saddle is a supportive structure for the sitting of the horseman on the back of the horse, and it has different shapes. The saddle whch was covered with gold, is suitable for kings, and some of them are covered with white silver, each of which may be embossed and not embossed, for more information see: (Abdel Nasser Yassin, Manazir Alfurusiat Fe Daw Funun Alkhazf Al Islami, Zahra Al Sharq Library, $1^{\text {st }}$ Edition, Cairo, 2005, p. 35). The first model known saddle-like equipment were fringed cloths or pads used by Assyrian cavalry around 700 BC., for more information see: (Russei (H.P.),Saddlelance Stirrup, university of okhama,1981. p. 18). The appearance of the solid structures of the saddles in Asia in 200 B.C., and then the Romans in the $1^{\text {st }}$ century B.C. contributed in the development of the stirrups to be in its current form, for more information see: (Bennett (D.), The Roots of new world, Amigo Puplications inc, 1998, p.100).

(5) Gauronski (R.S.), Some Remarks On the Origins and Construction of The Archeologia (Archaeology,Roman Military Saddle), Vol 55, 2004. pp.31, 40.

(6) The region of central Asia is the original home of the horse, but it is not known that the first ancestor of the horse, whose bones are similar to the bones of the wild horse, and it has been found on many parts of the horses in the regions of Iran and Iraq dating back to (3000) B.C. In 2000 B.C., the horse was come to Syria and then to Egypt. for more information see (Mahmoud Saif Eddin Ahmed, Wasaeil Al Nnaql Walmuasalat Albarria Fe Misr Al Qadima, Master Thesis, unpublished, Faculty of Archeology, Cairo University, 2002, p. 86.). 
being a toe loop that held the big toe and was used in the temple of Sanchi in India late in the second century B.C. This ancient foot support consisted of a looped rope for the big toe which was at the bottom of a saddle made of fiber or leather. Such a configuration was suitable for the warm climate of South and Central India, where people used to ride horses barefoot ${ }^{(7)}$.

While the first model of a rider with paired stirrups was known in China in one of the tombs of Jin Dynasty in 322 A.D. ${ }^{(8)}$, the stirrups were later transferred to Arabs via the Byzantine State in the $5^{\text {th }}$ and $6^{\text {th }}$ centuries A.D. ${ }^{(9)}$ During the Islamic eras, the stirrup developed in terms of their raw materials, as the primary sources from which stirrups were made of were wood and leather. Yet, they were made of iron during the period of Al-Muhallab Ibn Abi Sufra, also known as Abu Sa'id, who was appointed by Al-Hajjaj Ibn Yusuf Al-Thaqafi as the commander of Islamic armies in the city of Khorasan (77 - 82 A.H. / 697 - 702 A.D. ) ${ }^{(10)}$ Al Mubarrad mentioned in his book "The Kamil" (the perfect one) that stirrups were made of wood then iron by Al-Muhallab Ibn Abi Sufra. ${ }^{(11)}$

This interest was continued in the Mamluk period where there were private markets for tools of horses such as Almahamazien and Legmin markets. ${ }^{(12)}$ The stirrup was

(7) Lynn (T.),Medieval Technology and Social Change, Oxford University Press, 1964, p.14.

(8) John (H.M.), The Eastern Origins of Western Civilization, Combridgs Universitey Press, 2004, p.30.

(9) Shaid (I.), Byzantiun and The Arabs In The 6th Century,Volume II, Part 2, Harvard Mass, 1995, p.573.

(10) for more information about Al-Muhallab Ibn Abi Sufra see: (Nafie Tawfiq al-Aboud, Al-Muhallab Ibn Abi Sufra Wa dawrihim Fe Al Tarikh, University of Baghdad, Baghdad, 1976, p. 37 / Mahmoud Khattab Shit, Qadat Fath Al Send Wa Afganistan, Dar bin Hazm, $1^{\text {st }}$ Edition, Beirut, 1998, p. 170.).

(11) Al Mubarrad (Al Imam Abi Al-Abbas Mohammad Ibn Yazid 210-285 A.H.), AlKamil, Tahqiq Muhammad Ahmad Al-Dali, $2^{\text {nd }}$ Edition, Al-Resalah Foundation, Beirut, Lebanon, 1998, p. 117.

(12) Al-Maqrizi mentioned that horse tools had special markets where the Mamluks were provided with what they needed, such as the market for Almahamazien and Legmin. In 
preserved in a place inside the citadel called the "Stirrup Khana." (13) It was supervised by a person known as "AlMahtar."(14)

During the Ottoman era, great interest was devoted to horse equipment, where there was an employee at the Ottoman palace called as "Dal pant basic" who was responsible for horse saddles that include the horseshoe and stirrup. ${ }^{(15)}$ In Egypt, saddle industry flourished where it was made in the central capital "Cairo" (16) in the workshops of iron works beside El-Rappa near Bab Zuwaila. In fact, the stirrup is yet to be made at this area. ${ }^{(17)}$

\section{Function and Shape:}

Stirrups have many functions such as: holding the feet for support while riding animals as horses, mules and camels, where

these markets there are a large number of painters and makers of inlaying to draw Lejm, stirrups and Almahamez. for more information see: (Al-Maqrizi (Taqqi Eddin Ahmad), Al Mawaeiz Wa Ietabar Bizikr Alkhitat Wa Alaathar, Tahqiq Muhammad Zainham and Madiha Al-Sharqawi, Rajieaho Wa dabt Huamesh Ahmed Ziadeh, Part II, ${ }^{\text {st }}$ Edition, 1997, Cairo, p. 588.).

(13) Al-Rakabakhanah is the place where it has horse riding equipment, including saddles, Lejm, cannabish, Aleaby, Alaijlal and Almakhaly etc.. for more information see: (AlQalqashandi (Abi Al-Abbas Ahmad 821 A.H./1418 A.D.), Sobh Al Aeshaa Fe Sinaeat Al Ensha, Matbaeat Dar Al-ktub Al Misria, Part IV ,1340 A.H./1922 A.D, Cairo, p.12) (Nabil Mohamed Abdel Aziz, Alkhayl Wa Riadataha Fe Asr Salatin Al Mamalik, The Anglo-Egyptian Library, Cairo, 1976, p. 101.) - (Mohammed Qandil Albakli, Al Taerif Bimustalahat Sobh Al Aeshaa, Al Hayya Al Masria Al Amma Lilkitab, Cairo, 1984, p. 161.).

(14) Al-Mahtar means the grand. It is the title given to a large group of house boys, such as Mahtar Sharab Khana, Mahtar al-Tast Khanh, and Mahtar Al-Rakabakhanah who is responsible for the number of horses, for more information see:, Al-Qalqashandi, Sobh Al Aeshaa, Part V, p. 470.) - (Nabil Mohamed Abdel Aziz, Alkhayl Wa Riadataha Fe Asr Salatin Al Mamalik, p. 102.) - (Mohammed Qandil Albakli, Al Taerif Bimustalahat Sobh Al Aeshaa, p. 333.) - ( Ahmed Mohammed Edwan, Al Askaria Al Islamia Fe Al Asr Al Mamlwki, Dar Alam Al-kitab Lilnashr Wa Altawzie, Riyadh, 1985, p. 92.).

(15) Cenkmen (E.), Osmanli Sarayi Ve Kiyafetleri, Istanbul, 1948, p. 50.

(16) Mohammed Abdel Hafeez, Dawr Aljaliaat Al-Ajnabia Wa Al-Arabia fe Al-Hayya AlFannia fe Misr fe Al-Qarnayn 18 Wa 19, Derasa Atharia Fannia Hadaria Wathaqiyya, PhD Thesis, the Faculty of Archeology, Cairo University, 2000, p. 277.

(17) Nasser Ibn Ali Al-Harithi, Tohaff Al-Awany Wa Al-Adwat Al-Maedinia Fe Al-Asr Al-Othomany, PhD Thesis, Department of Historical and Cultural Post Studies, College of Sharia and Islamic Studies, Umm Al-Qura University, Riyadh, 1989, p. 34. 
the person places the left foot inside the stirrup then jumps with the right foot. ${ }^{(18)}$ Thus, stirrups help horsemen to be more stable over the saddle, to use the sword in a more effective way without the risk of falling, and to use spears with the back part of the saddle. ${ }^{(19)}$ The stirrups in this study were made in a way that fits the foot's position in order to increase the stability of those who use them. The base of stirrups was designed to open the front and the back to protect the horsemen's foot from falling (Pl.1, 2, 3). The base of the stirrups was designed according to the foot length $(P l$. 1) with a support made of a piece of wood for more stability, and to surround the foot's front part to increase the balance. Through the above, it becomes clear that stirrups were designed to serve their function.

\section{The Raw Materials}

One type of raw materials has been used in the industry of stirrups of this study, which is iron.

\section{Iron}

Steel or iron was used in making the stirrups (Pl.1.2.3). It is a solid metal and heat-resistant, but it rusts quickly and is affected by acids. Iron is extracted from Hematite, Magnetite, and Limutite ${ }^{(20)}$. It needs heating at a degree up to $110-150$ degrees, and furnaces operating in carbon coal. After that, it is filtered and purified, heated, hammered and exposed to multiheating till it reaches the appropriate position for using. ${ }^{(21)}$ Iron is considered one of the most important metals that were known by the Ottomans, and it was ornamented with various types of

(18) Abdel Nasser Yassin, Manazir Alfurusiat Fe Daw Funun Alkhazf Al Islami, pp. 36, 277.

(19) John (H.M.), The Eastern Origins of Western Civilization, Combridgs Universitey Press, 2004, p.30.

(20) Hafiz Shams El-Din Abdel Wahab, Al-Jeyulujia Al-Fiziqia Wa Al-Tarikhia, Dar AlFikr Al-Arabe, $1^{\text {st }}$ Edition, Cairo, 2006, p. 79.

(21) Olker Argin Soe, Tatawwur Fin Al-Maeadin Al-Islamya Munz Al-Bidaya Hatta Nihayat Al-Asr Al-Seljuky, translated by Safsawi Ahmed Al-Qattouri, Supreme Council of Culture, $1^{\text {st }}$ Edition, Cairo, 2005, pp. 82,83. 
decorations. During the late Ottoman period (the $13^{\text {th }}$ century A. H. / the $19^{\text {th }}$ century A. D.), iron industries played an important role in providing the demands of the Egyptian society of the blacksmithing tools needed. ${ }^{(22)}$

\section{Manufacturing Method}

\section{Casting in the mold}

This method is one of the most ancient ways that manufacturers used it forming metals. It was known as "automatic formation." (23) This method was used in making the stirrups in this study $(\mathrm{Pl} .1,2,3)$. The method of casting in the mold is characterized by precision and perfection in the implementation of decorations where molten metals were poured into molds for the required shapes of stereoscopic shapes and elements. The method of casting in the mold is an industrial method in the first place, and at the same time represents a decorative method that embodies the various decorative elements carved in the mold. ${ }^{(24)}$

\section{Decoration Methods}

\section{Engraving}

The prominent engraving was used in the decoration of stirrups $(P l .1,2.3)$. This method was carried out by digging around the decorative shapes that the artist wanted to prominently show on the surface of the metal. ${ }^{(25)}$ This style was called "kaborting" by the Turks and by manufacturers in Egypt, while was known as "Ooamh prominent" in Hijaz. It has occupied a decent position in the Ottoman period in the

(22) Mohammed Abdel Aziz Marzouk, Al Funun Al-Zokhrafia fe Al-Asr Al-Othomany, Al Hayya Al Masria Al Amma Lilkitab, $1^{\text {st }}$ Edition, Cairo, 1974, p. 149.

(23) Douglas (B.), Islamic Metal Work in the British Museum, London, 1994, p. 14.

(24) Shadia El-Desouky, Taqim Maktab Min Al-Nahas Al-Mamwwah Bilmeyina Yonsib Lilusrah Al-Alawia (unpublished), Journal of Faculty of Archeology, Cairo University, the $16^{\text {th }}$ Edition, 2012, Cairo University Press, Cairo, p. 233.

(25) Said Meselhi, Adwat Wa Awany Al-Matbakh Al-Maedinia fe Al-Asr Al-Mamluky, PhD Thesis, unpublished, Faculty of Archeology, Cairo University, 1983, p. 259. 
decoration of metals, which might be due to the reluctance of manufacturers to use the inlaying "Takfit" which was widely used before that. The method of engraving has been used since the end of the $12^{\text {th }}$ century A.H. / the $18^{\text {th }}$ century A.D., making manufacturers use the European style in the ornamentation which depends on prominence in the first place. ${ }^{(26)}$

\section{Gilding (27)}

Gilding was used in the decoration of the stirrups in this study (Pl.1, 2, 3). It was limited to decorative elements only. Gilding was done on the stirrups made of iron in which it as more appropriate for such types of masterpieces. ${ }^{(28)}$ This method was known in the Ottoman era as (Altzmik). ${ }^{(29)}$ Examples of the metallic artifacts that were painted with gilding are the candlesticks of Minister Suleiman Pasha Al-Khadem (947 A. H. / 1540 A.D.) preserved in the Museum of Islamic Art, and carrying the registration numbers (4395-4396-4397) ${ }^{(30)}$, and the two stirrups in the special collection from the Ottoman period dated in the 13th century A.H./ the 19th century A.D (pl. 4,5) $)^{(31)}$

(26) Nasser Ibn Ali Al-Harithi, Tohaff Al-Awany Wa Al-Adwat Al-Maedinia Fe Al-Asr Al-Othomany, p. 58.

(27) The gilding components are mixed from the gold with a little silver and copper, and are cast in the form of an alloy, then pressed between the two cylinders and hammared on the letters, and extracted from thin golden strips, its thickness is $1 \mathrm{~cm}$, and these gold chips must to be crushed to become a golden sol is used by brush in the composition of decorative elements. There are different ways to sol the powder of the golden foils, either by adding Arabic gum, glaucoma or other materials, and to give the used golden sol in gilding more luster and glittering color adding to it a little saffron, and for getting the appropriate texture add a little of the boiled juice of the grapes to give a more softness. for more information see: (Shadia El-Desouky, Fan Al-Tazhheb Al-Othomany fe Al-Masahif Al-Athria, Cairo, $1^{\text {st }}$ Edition, Cairo, 2002, pp. 45,39.).

(28) Mohammed Ahmed Zahran, Funun Ashghal Al-Maeadin Walttohaf, Anglo-Egyptian Library, $1^{\text {st }}$ Edition, Cairo, 1965, p. 532.

(29) Abdel Rahman Zaki, Al-Sayf fe Al-Alam Al-Islami, Cairo, 1957, p. 158.

(30) Shadia El-Desouky, Taqim Maktab Min Al-Nahas Al-Mamwwah Bilmeyina, p. 245.

(31) https://s-media-cache-

ak0.pinimg.com/originals/4e/10/c3/4e10c3d01aceef07f73fb439451c3994.jpg. 


\section{Decorations}

The stirrups of this study are characterized by the appearance of two types of decorations, as follows:

\section{The Vegetal Motifs}

Floral motifs have appeared, ornamenting the two exterior sides of the first stirrup with forms of a bouquet of repeated roses with open petals flowers and flower buds (Pl.1). It is noticed that roses and flowers often relate between the legs which are decorated with interlaced branches of leaves (Fig. 1). These branches represent the general structure of the decorative theme which consists of roses, flowers, and their buds.

In fact, one repeated flower composes the decorative theme, which is the flower of carnation, while the branches overlap in a spiral way. The leaves were carried out in harmony with the curves of the stems and branches. The branches and roses appear separately on both sides of the stirrups (Pl.1), (Fig. 1). Bouquets of roses and flowers are among the most decorative elements used on all applied arts. Among the examples are the bouquets of roses that decorated many masterpieces dating back to the $13^{\text {th }}$ century A. H. / the $19^{\text {th }}$ century A.D., such as the beginning of the Koran preserved in the University of Istanbul Library ${ }^{(32)}$, as well as the cover of a box of wood preserved in the Museum of Manial Palace. ${ }^{(33)}$ This is in addition to the acanthus leaves that decorate the exterior sides of the second stirrup (Pl.2), which were characterized by pointed sides with a prominent sweat in the middle (Fig. 2). The acanthus leaves dated back to the Greeks and the Romans. They were made of round edges, and mainly used for decoration, ${ }^{(34)}$ then they were transferred to the

(32) Shadia El-Desouky, Fan Al-Tazhheb, (Pl. 28).

(33) Ahmed Riad, Al-Tohaf Al-Khashbia Fe Asr Muhammad Aly Fe Daw Majmueat AlTohaf Al-Ththabitah Walmanqulah Almahfuzah Bimuttahaf Qasr Al-Manil BelQahirah, Master Thesis, Faculty of Archeology - Cairo University, Cairo, 2010, Pl. 26A - B.

(34) Ahmed Youssef, Tarikh Al-Torz Al-Zokhrafia Wa Al-Funun Al-Jamila, Cairo, 1948, p. 56. 
Islamic Art, and appeared in the early Islamic architecture, as seen in some of the mosaic decorations that adorn the Dome of the Rock (72 A.H. / 695 A.D.). ${ }^{(35)}$

\section{Pomegranate}

The pomegranate branches and leaves appeared among the ornaments that adorn the sides of the second stirrup (Pl.2), (Fig. 2 ). Pomegranate is one of the fruits that has been known since the ancient times, ${ }^{(36)}$ but it received the attention of the Turks from the $8^{\text {th }}$ century A.H., the $14^{\text {th }}$ century A.D. While before that it did not have a clear impact on the decorations of the Ottoman arts. ${ }^{(37)}$ Pomegranate is considered one of the fruits of Paradise, as it was mentioned in the Holy Quran favoring it with the palm tree over all other fruits, ${ }^{(38)}$ Allah said "In them (both) will be fruits and date-palms and pomegranates". (39)

\section{The Geometric Motifs}

Islamic art included the ornamentation as a basic type or pattern of it. ${ }^{(40)}$ The geometric motifs in Islamic civilization have had a special significance and a unique characteristic that is unparalleled in any other civilization.

This has helped the Muslim artist to distance himself from the tradition of nature and simulation of reality, so as to stay away

(35) Suad Maher, Al-Funun Al Islamia, Al Hayya Al Masria Al Amma Lilkitab, Cairo, 1986, p. 217.

(36)Suad Maher, Al-Funun Al Islamia, p. 219.

(37) Kawthar Abul-Fotouh, Derasa Lisajajed Jordiz Fe Daw Mutthaf Qasr Al-Manial , Supreme Council of Antiquities, Cairo, 2003, p. 10.

(38) Shadia Hassan Abdel Rahman, Wasf Al-Jannah Fe Al-Quran Al-Karem Wa Atharh Fe Al-Shier Al-Al-Islami Hatta Nahayet Al-Asr Al-Amawy, Maktaba Dar Al-Qahera, Cairo, 2004, p. 200.

(39) Al-Quran Al-Karem, Surat Al-Rahman, verse 68.

(40) Galal Eldien (G.M.), Islamic and religious building the architecture magazine Egyptian, Architects, association, $2^{\text {nd }}$ years, Cairo, 1984, p.18

(41) Abu Saleh al-Alfi, Mujaz Fe Tarikh Al-Fann Al-Aam, Dar Al-Qalam, Beirut, 1965, p. 56. 
from the emulation of the Creator Almighty. ${ }^{(42)}$ In addition to that, Arab Muslims excelled in several sciences, such as Arithmetic and Engineering in particular. ${ }^{43}$ ) Accordingly, geometric motifs adorned the external aspects of the third and fourth stirrups, with varying patterns $(\boldsymbol{P l} .3)$ as follows:

\section{Triangles}

The triangle is originally considered to consist of straight lines. ${ }^{(44)}$ Triangles have appeared among the motifs that adorn the exterior two sides of the two stirrups. (Pl.3), (Fig. 3), and implemented in a proper manner. ${ }^{(45)}$ They have appeared to adorn the façade of the palace of the Mushatta (123-133 A.D. / 740-750 A.D.) in the desert of the Levant, and in the two stirrups in special collection from the Ottoman period dating back to the 13th century A.H./ the 19th century A.D (pl. 5) ${ }^{46}$. The triangle has some symbolism, especially in ancient religious beliefs, which have nothing to do with Islam. ${ }^{(47)}$

(42) Ibrahim Wagdy, Ashghal Al-Rokham fe Al-Emara Al-Dinia fe Madinat Al-Qahera fe Ahd Mohammed Aly Wa Khulafaah, Master Thesis, Faculty of Archeology, Cairo University, 2007, p. 141.

(43) Ahmed Fekry, Awamil Alwahdah Fe Al-Athar Al-Islamia Bilbilad Al-Arabia, Arab Organization for Education, Culture and Science, Studies in Islamic Archeology, Cairo, 1979, p. 6.

(44) Essam Arafa Mahmoud, Tatawr Asaleeb Al-Takwin Fe Al-Zakharif Al-Jodaria Bimasajid Al-Qahera Fe Asr Al-Mamalik Al-Bahria, PhD Thesis, Faculty of Archeology, Cairo University, 1987, p. 133.

(45) The triangle symbolizes to the earth in the case of its execution in the form of noninverted, while it symbolizes to the sky when it is executed in an inverted way. for more information see: (Ali Zein Al-Abidin, Al-Masagh Al-Shaebi fe Misr, $1^{\text {st }}$ Edition, Cairo, 1974, p. 155.).

(46) httpswww.pinterest.compin402720391664489896.

(47)The triangle was found in the decorations of the ancient Egyptian art and Coptic art, in addition to it is an important element in the popular beliefs against the eye and magic, where the Turks used to work of veils in the form of triangles to be safed from the eyes of the green-eyed, for more information see: (Mahmoud Ibrahim Hussein, Al-Khazaf AlIslami Fe Misr, Maktabit Nahdet Al-Sharq, Cairo, 1984, p. 130.). 


\section{Circles}

The circle is one of the geometric motifs that appeared on both sides of stirrups (Pl.3), (Fig. 3). We notice that the use of circles helps to create small geometric forms such as triangles that appeared to embellish the sides of the two stirrups and divide it into different geometric areas. The circle is geometrically generated by the movement of a beam emanating from the central point at a specific level of the sphere and then takes in the rotation around this point fixed at a constant height that does not change. Therefore, the relation between the central point and the circle is a relationship of unity and similarity between the point and the parts of the line drawn around it. ${ }^{(48)}$

\section{Zigzag Decorations}

They are broken lines that were executed in a repetitive manner. ${ }^{(49)}$ This decoration has appeared in a frame among the other geometric motifs that adorn the two sides of the two stirrups (Pl.3), (Fig. 3). Zigzag decorations have appeared to adorn the façade of the palace of the Mushatta (123-133 A.D. I 740-750 A.D.) in the desert of the Levant, in the interiors of the vaults of one of the arcades of the Mosque of Ahmad ibn Tulun, and then spread to use in the decoration of niches of the mihrab, marble floors, roofs of domes and their interiors and the bodies of minarets, especially in the Mamluk era. These ornaments continued in the same way in the Ottoman architecture and the era of Muhammad Ali, such as the mihrab of the Rewaq AlAbbasi in Al-Azhar mosque (1135 A.H. / 1722 A.D). ${ }^{(50)}$

(48) Azza Abd El-Moaty, Al-Zakhrifa Ala Al-Tuhaf Al-Fannia Fe Misr Al-Islamia Hatta Nahayat Al-Qarn 4 Al-Hijri / 10 Al-Melady , PhD Thesis, unpublished, Faculty of Archeology, Cairo University, 2002, p. 141.

(49) Adnan Mohammed Fayez Al-Harithi, Emarat Al-Madrasa Fe Misr Wa Al-Hejaz Fe Al-Qarn 9 Al-Hijri / 15 Al-Melady, Derasa Moqarna, King Fahad National Library, Riyadh, 1997, p. 125.

(50) Ibrahim Wagdy, Ashghal Al-Rokham, pp. 152, 153. 


\section{Pearl's Beads}

This decoration is known as the pearl, the ornamentation of pearl or the decoration beads and disks. ${ }^{(51)}$ They are represented in the form of dense granules. Pearl's beads have appeared to adorn the frames of the decorative elements on both two sides of two stirrups (Pl.3), (Fig. 3). The origin of this ornamentation dated back to the Sassanid art and then moved to Islamic art, and has been known as the pearl beads ${ }^{(52)}$. This embellishment appeared to adorn the sides of Mohammed Ali's shrine (1256 A.H. / 1840 A.D.). ${ }^{(53)}$

\section{History}

Although the group of stirrups does not contain dated writings, through the evidence provided, they can be dated based on the images of the Ottoman manuscripts, which showed the forms of these stirrups. We see the curved shape of the stirrups in a miniature representing the arrival of Sultan Suleyman Al Qanony at Bogurdelen ${ }^{(54)}$, from the manuscript of Suleyman Nama, dated (966 A.H. / 1558 A.D.), (Pl.6) and preserved in the Museum of Tobkapu Sarai in Istanbul. The triangle shape is represented in a miniature depicting Kanan Pasha and his armies $^{(55)}$ from an album dated 1040 A.H. / 1630 A.D., preserved in Istanbul's Tuppakabu Sarai Museum (pl.7). This is in addition to the decorative elements that appeared on the stirrups such as bouquets of roses, carnations, pomegranates, and acanthus leaves, and also geometric decorations such as triangles and circles similar to the Ottoman decorative elements. Hence, the style of decoration in gilding came similar to the style of

(51) Farid Shafei, Al-Emara Al-Arabia Fe Misr Al-Islamia Wa Asr Al-wlah, Al Hayya Al Masria Al Amma Lilkitab, Cairo, 1994, p. 177.

(52) Mohammed Abdel Hafeez, Ashghal Al-Maeadin fe Al-Qahira Al-Othmania, Master Thesis, Faculty of Archeology, Cairo University, Cairo, 1995, p. 195.

(53) Ibrahim Wagdy, Ashghal Al-Rokham, pp. 155.

(54) Atil (E.), Suleymanname, The Illustrated History of Suleyman The Magnificent, New York ,1986, Pl. 7.

(55) Atil (E.), Suleymanname,Pl. 186. 
decoration in the same manner on the metal masterpieces in the Ottoman era, and family of Muhammad Ali. Thus, through the decorative elements appearing on the stirrups (pl.4.5), it can be stated that the stirrups date back to the 13th century A.H./ the 19 th century A.D.

\section{The Descriptive Study:}

\section{Plate Number: (1).}

Type of the object: A stirrup

Raw Material: Iron.

Place of preservation: Gayer-Anderson Museum in Cairo.

Register number: 585.

Description:

This plate represents a stirrup made of iron, composed of a curved base decorated with floral motifs on the outsides. They are forms of a bouquet of the repeated roses with flowers of open petals, as well as flower buds. The style of gilding as well is used in the ornamentation of the decorative elements. We notice that there is a piece of wood in the base of the stirrups from the inside for more stability of the foot. The stirrup ends from the top with a ring for placing the tied saddle belt. 


\section{Plate Number: (2).}

Type of the object: A stirrup

Raw Material: Iron.

Dimensions: 14 X $14 \mathrm{~cm}$.

Place of preservation: Gayer-Anderson Museum in Cairo.

Register number: 594.

Description:

This plate represents a stirrup made of iron, composed of a triangle base decorated with floral motifs on the outsides. They are forms of branches and flowers of roses, acanthus leaves, in addition to branches, leaves, and fruits of pomegranates. The method of gilding has been used in the decoration of the ornamental elements. The stirrup ends from the top with a ring for placing the tied saddle belt.

\section{Plate Number: (3).}

Type of the object: two stirrups

Raw Material: Iron.

Dimensions: 15.5 X $12.5 \mathrm{~cm}$.

Place of preservation: Gayer-Anderson Museum in Cairo.

Register number: 581 - 582.

Description:

These two plates represent two stirrups made of iron, each of them is composed of a triangle base and two handles decorated with geometric motifs from the outside. These ornaments are triangles, circles, pearl's beads and zigzag shapes. The method of gilding has been used in the decoration of the ornamental elements. The stirrup ends from the top with a ring for placing the tied saddle belt. 


\section{THE RESULTS}

- The study dealt with the descriptive and analytical studies of four stirrups in Gayer-Anderson Museum in Cairo published for the first time.

- The study clarified that Muslims played an important role in the development of the stirrups, in which they were made of wood and leather, and in the Umayyad era were made of iron by Al-Muhallab Ibn Abi Sufra.

- The study showed the types of decorations on the stirrups, which were limited to geometric and vegetal motifs, and the absence of writings, perhaps because the stirrups were used for the foot.

- The parts of the stirrups were related to their function, in which they consisted of a base, the handles and the ring to install people on the animals during riding and fighting.

- The raw material used in the manufacture of the stirrups in this study was iron.

- The method of decoration was used on the stirrups of this study, where the limited decorative elements were drawn into gold. Also, the embellishment of the gilding greatly spread in the decoration of the metal artifacts from the late Mamluk era and the beginning of the Ottoman era. 


\section{BIBLIOGRAPHY:}

\section{Al-Quran Al-Karem}

\section{Sources :}

- Al Mubarrad (Al Imam Abi Al-Abbas Mohammad Ibn Yazid 210-285 A.H.), Al-Kamil, Tahqiq Muhammad Ahmad Al-Dali, $2^{\text {nd }}$ Edition, AlResalah Foundation, Beirut, Lebanon, 1998.

- Al-Maqrizi (Taqqi Eddin Ahmad), Al Mawaeiz Wa Ietabar Bizikr Alkhitat Wa Alaathar, Tahqiq Muhammad Zainham and Madiha Al-Sharqawi, Rajieaho Wa dabt Huamesh Ahmed Ziadeh, Part II, $1^{\text {st }}$ Edition, Cairo, 1997.

- Al-Qalqashandi (Abi Al-Abbas Ahmad 821 A.H./1418 A.D.), Sobh Al Aeshaa Fe Sinaeat Al Ensha, Matbaeat Dar Al-ktub Al Misria, Parts IV \& V, Cairo, 1340 A.H./1922 A.D.

- Ibn Manzoor (Gamal Edin Abu Al Fadil Mohammed Ibn Makram 711 A.H./1371 A.D.), Lisan Al Arab, Vol. III, Dar Al Ma'arif, Cairo, No date.

\section{Arabic References :}

- Abdel Nasser Yassin, Manazir Alfurusiat Fe Daw Funun Alkhazf Al Islami , Zahra Al Sharq Library, $1^{\text {st }}$ Edition, Cairo, 2005.

- Abdel Rahman Zaki, Al-Sayf fe Al-Alam Al-Islami, Cairo, 1957.

- Abu Saleh al-Alfi, Mujaz Fe Tarikh Al-Fann Al-Aam, Dar Al-Qalam, Beirut, 1965.

- Adnan Mohammed Fayez Al-Harithi, Emarat Al-Madrasa Fe Misr Wa AlHejaz Fe Al-Qarn 9 Al-Hijri / 15 Al-Melady, Derasa Moqarna, King Fahad National Library, Riyadh, 1997.

- Ahmed Fekry, Awamil Alwahdah Fe Al-Athar Al-Islamia Bilbilad AlArabia, Arab Organization for Education, Culture and Science, Studies in Islamic Archeology, Cairo, 1979.

- Ahmed Mohammed Edwan, Al Askaria Al Islamia Fe Al Asr Al Mamlwki, Dar Alam Al-kitab Lilnashr Wa Altawzie, Riyadh, 1985.

- Ahmed Youssef, Tarikh Al-Torz Al-Zokhrafia Wa Al-Funun Al-Jamila, Cairo, 1948.

- Ali Zein Al-Abidin, Al-Masagh Al-Shaebi fe Misr, $1^{\text {st }}$ Edition, Cairo, 1974.

- Farid Shafei, Al-Emara Al-Arabia Fe Misr Al-Islamia Wa Asr Al-wlah, Al Hayya Al Masria Al Amma Lilkitab, Cairo, 1994.

- Hafiz Shams El-Din Abdel Wahab, Al-Jeyulujia Al-Fiziqia Wa Al-Tarikhia, Dar Al-Fikr Al-Arabe, $1^{\text {st }}$ Edition, Cairo, 2006. 
- Kawthar Abul-Fotouh, Derasa Lisajajed Jordiz Fe Daw Mutthaf Qasr AlManial, Supreme Council of Antiquities, Cairo, 2003.

- Mahmoud Ibrahim Hussein, Al-Khazaf Al-Islami Fe Misr, Maktabit Nahdet Al-Sharq, Cairo, 1984.

- Mahmoud Khattab Shit, Qadat Fath Al Send Wa Afganistan, Dar bin Hazm, $1^{\text {st }}$ Edition, Beirut, 1998.

- Majmae Allugha Alarabia, Almoajam Alwasit, $1^{\text {st }}$ Part, Egypt, $2^{\text {nd }}$ Edition, Cairo, 2004.

- Mohammed Abdel Aziz Marzouk, Al Funun Al-Zokhrafia fe Al-Asr AlOthomany, Al Hayya Al Masria Al Amma Lilkitab, $1{ }^{\text {st }}$ Edition, Cairo, 1974.

- Mohammed Ahmed Zahran, Funun Ashghal Al-Maeadin Walttohaf, AngloEgyptian Library, $1^{\text {st }}$ Edition, Cairo, 1965.

- Mohammed Qandil Albakli, Al Taerif Bimustalahat Sobh Al Aeshaa, Al Hayya Al Masria Al Amma Lilkitab, Cairo, 1984.

- Nabil Mohamed Abdel Aziz, Alkhayl Wa Riadataha Fe Asr Salatin Al Mamalik, The Anglo-Egyptian Library, Cairo, 1976.

- Nafie Tawfiq al-Aboud, Al-Muhallab Ibn Abi Sufra Wa dawrihim Fe Al Tarikh, University of Baghdad, Baghdad, 1976.

- Olker Argin Soe, Tatawwur Fin Al-Maeadin Al-Islamya Munz Al-Bidaya Hatta Nihayat Al-Asr Al-Seljuky, translated by Safsawi Ahmed Al-Qattouri, Supreme Council of Culture, $1^{\text {st }}$ Edition, Cairo, 2005.

- Shadia El-Desouky, Fan Al-Tazhheb Al-Othomany fe Al-Masahif AlAthria, Cairo, $1^{\text {st }}$ Edition, Cairo, 2002.

- Shadia El-Desouky, Taqim Maktab Min Al-Nahas Al-Mamwwah Bilmeyina Yonsib Lilusrah Al-Alawia (unpublished), Journal of Faculty of Archeology, Cairo University, the $16^{\text {th }}$ Edition, Cairo University Press, Cairo, 2012.

- Shadia Hassan Abdel Rahman, Wasf Al-Jannah Fe Al-Quran Al-Karem Wa Atharh Fe Al-Shier Al-Al-Islami Hatta Nahayet Al-Asr Al-Amawy , Maktaba Dar Al-Qahera, Cairo, 2004.

- Suad Maher, Al-Funun Al Islamia, Al Hayya Al Masria Al Amma Lilkitab, Cairo, 1986. 


\section{Foreign References :}

- Atil (E.), Suleymanname, The Illustrated History of Suleyman The Magnificent, New York ,1986.

- Bennett (D.),The Roots of new world, Amigo Puplications inc,1998.

- Cenkmen (E.),Osmanli Sarayi Ve Kiyafetleri, Istanbul, 1948.

- Douglas (B.), Islamic Metal Work in the British Museum, London, 1994.

- Galal Eldien (G.M.), Islamic and religious building the architecture magazine Egyptian, Architects, association, $2^{\text {nd }}$ years, Cairo, 1984.

- Gauronski (R.S.), Some Remarks On the Origins and Construction of The Archeologia(Archaeology,Roman Military Saddle), Vol 55, 2004.

- John (H.M.), The Eastern Origins of Western Civilization, Combridgs Universitey Press, 2004.

- John (H.M.), The Eastern Origins of Western Civilization, Combridgs Universitey Press, 2004.

- Lynn (T.),Medieval Technology and Social Change, Oxford University Press, 1964.

- Russei (H.P.),Saddlelance Stirrup, university of okhama,1981.

- Shaid (I.), Byzantiun and The Arabs In The 6th Century,Volume II, Part 2, Harvard Mass, 1995.

\section{Dissertations :}

- Ahmed Riad, Al-Tohaf Al-Khashbia Fe Asr Muhammad Aly Fe Daw Majmueat Al-Tohaf Al-Ththabitah Walmanqulah Almahfuzah Bimuttahaf Qasr Al-Manil BelQahirah, Master Thesis, Faculty of Archeology - Cairo University, Cairo, 2010.

- Azza Abd El-Moaty, Al-Zakhrifa Ala Al-Tuhaf Al-Fannia Fe Misr AlIslamia Hatta Nahayat Al-Qarn 4 Al-Hijri / 10 Al-Melady , PhD Thesis, unpublished, Faculty of Archeology, Cairo University, 2002.

- Essam Arafa Mahmoud, Tatawr Asaleeb Al-Takwin Fe Al-Zakharif AlJodaria Bimasajid Al-Qahera Fe Asr Al-Mamalik Al-Bahria, PhD Thesis, Faculty of Archeology, Cairo University, 1987.

- Ibrahim Wagdy, Ashghal Al-Rokham fe Al-Emara Al-Dinia fe Madinat AlQahera fe Ahd Mohammed Aly Wa Khulafaah, Master Thesis, Faculty of Archeology, Cairo University, 2007. 
- Mahmoud Saif Eddin Ahmed, Wasaeil Al Nnaql Walmuasalat Albarria Fe Misr Al Qadima, Master Thesis, unpublished, Faculty of Archeology, Cairo University, 2002.

- Mohammed Abdel Hafeez, Ashghal Al-Maeadin fe Al-Qahira Al-Othmania, Master Thesis, Faculty of Archeology, Cairo University, Cairo, 1995.

- Mohammed Abdel Hafeez, Dawr Aljaliaat Al-Ajnabia Wa Al-Arabia fe AlHayya Al-Fannia fe Misr fe Al-Qarnayn 18 Wa 19, Derasa Atharia Fannia Hadaria Wathaqiyya, PhD Thesis, the Faculty of Archeology, Cairo University, 2000.

- Nasser Ibn Ali Al-Harithi, Tohaff Al-Awany Wa Al-Adwat Al-Maedinia Fe Al-Asr Al-Othomany, PhD Thesis, Department of Historical and Cultural Post Studies, College of Sharia and Islamic Studies, Umm Al-Qura University, Riyadh, 1989.

- Said Meselhi, Adwat Wa Awany Al-Matbakh Al-Maedinia fe Al-Asr AlMamluky, PhD Thesis, unpublished, Faculty of Archeology, Cairo University, 1983.

\section{Electronic sites :}

- http://www.dictionary.com

- https://s-media-cache-

ak0.pinimg.com/originals/4e/10/c3/4e10c3d01aceef07f73fb439451c3994.jpg

- httpswww.pinterest.compin402720391664489896 


\section{List of Figures and Plates}

First: Figures

- Figure (1) decorations of the bouquet of the flowers from plate (1) done by the researcher.

- Figure (2) fruits of pomegranates, acanthus leaves and roses from plate (2) done by the researcher.

- Figure (3) various geometric ornaments from plate (3) done by the researcher.

Second: Plates

- Plate (1) represents a stirrup made of iron, register number 585, unpublished.

- Plate (2) represents a stirrup made of iron, 14 X $14 \mathrm{~cm}$, register number 594, unpublished.

- Plate (3) represents two stirrups made of iron, $15.5 \times 12.5 \mathrm{~cm}$, register numbers 581 - 582, unpublished.

- Plate (4) represents two stirrups, Ottoman period, (12AH18AD) Special collection, https://s-media-cache ak0.pinimg.com/originals/4e/10/c3/4e10c3d01aceef07f73fb439451c3994.jpg

- Plate (5) represents two stirrups, Ottoman period,

(12AH-18AD) Special collection,

https://www.pinterest.com.pin402720391664489896

- Plate (6) represents a miniature of the departure of Sultan Suleiman Al Qanony from the manuscript of Suleiman Nama, dated (966 A.H. / 1558 A.D.), and preserved in the Museum of Tobkapu Sarai in Istanbul, about Atil.E, Suleymanname, Pl.7.

- Plate (7) represents a miniature of Kanan Pasha and his armies from an album dated 1040 A.H. / 1630 A.D., preserved in Istanbul's Tuppakabu Sarai Museum, about Ati 1.E, Suleymanname, $P l .186$ 
The Figures

\begin{tabular}{|c|c|c|}
\hline Plate Number & Registry Number & Price \\
\hline$\underline{1}$ & 585 & $500 \mathrm{~m}$ \\
\hline$\underline{2}$ & 594 & 1 L.E. \\
\hline$\underline{3}$ & $581-582$ & $800 \mathrm{~m}$ \\
\hline
\end{tabular}

Table (1) shows the prices of stirrups through the museum register

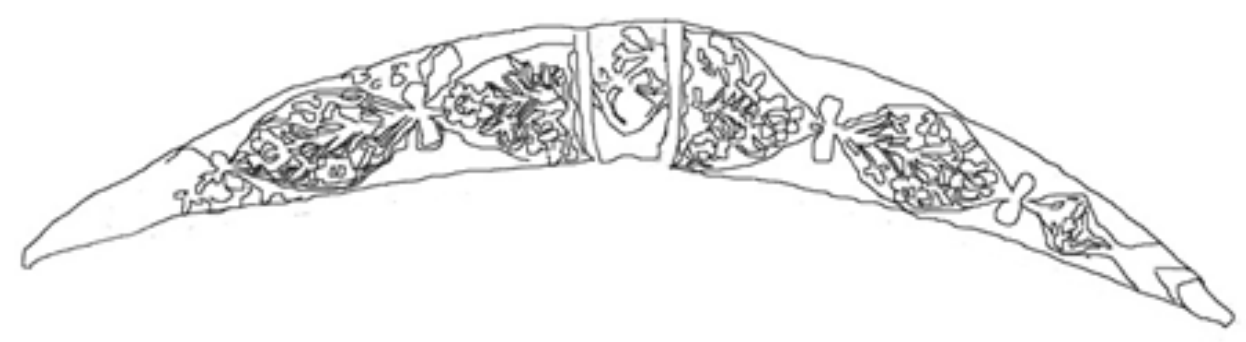

Figure (1) decorations of the bouquet of the flowers from plate (1), done by the researcher

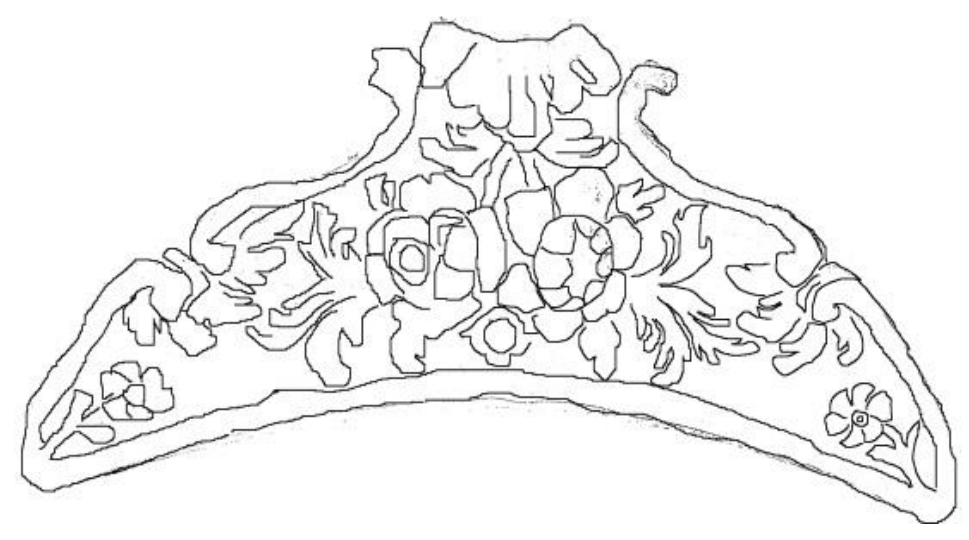

Figure (2) fruits of pomegranates, acanthus leaves and roses from plate (2), done by the researcher. 


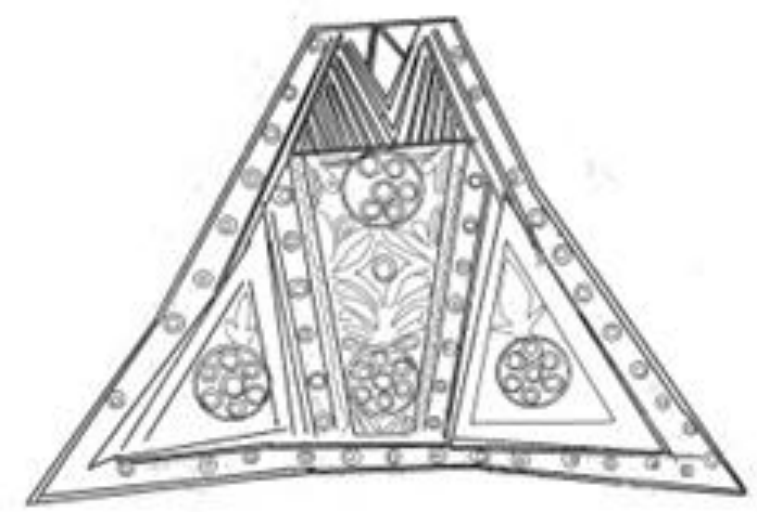

Figure (2) various geometric ornaments from plate (3), done by the researcher.

\section{The Plates:}

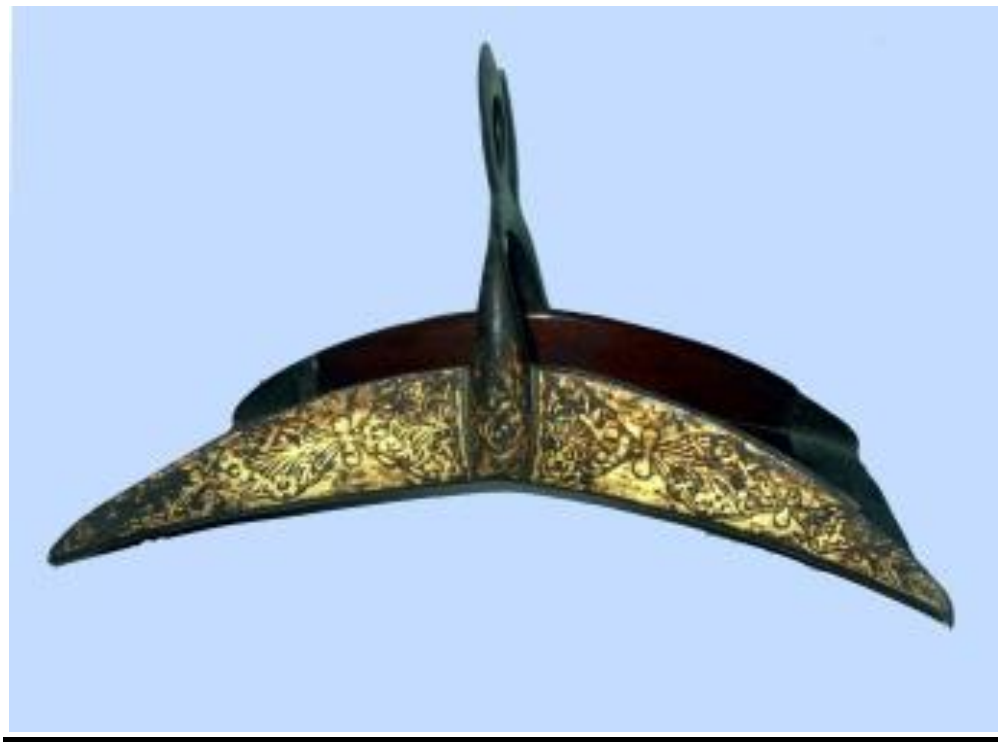

Plate (1) represents a stirrup made of iron, register number 585, unpublished. 


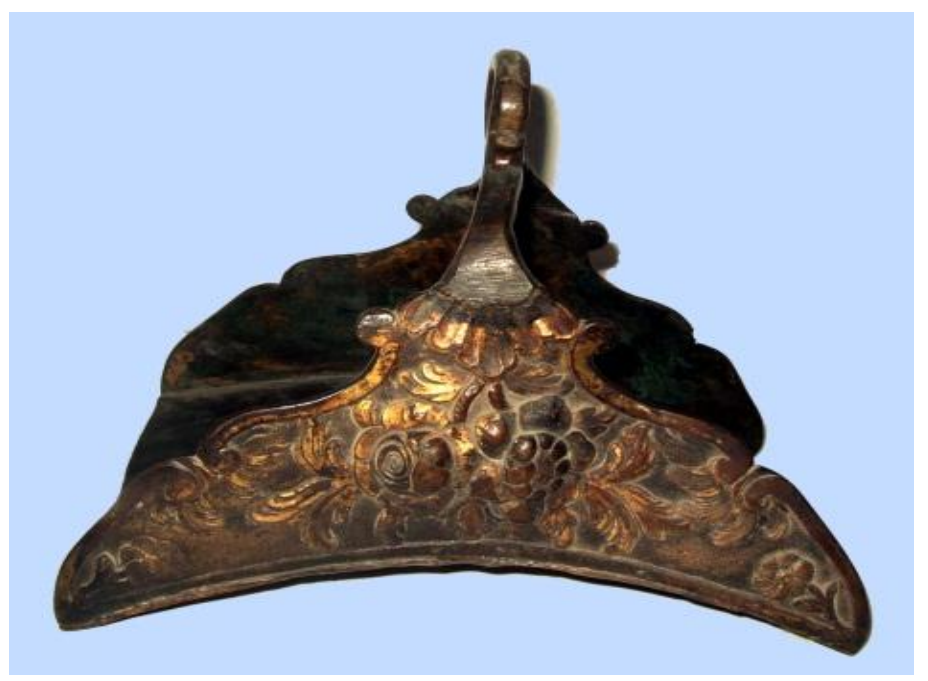

Plate (2) represents a stirrup made of iron, $14 \times 14 \mathrm{~cm}$., register number 594, unpublished.
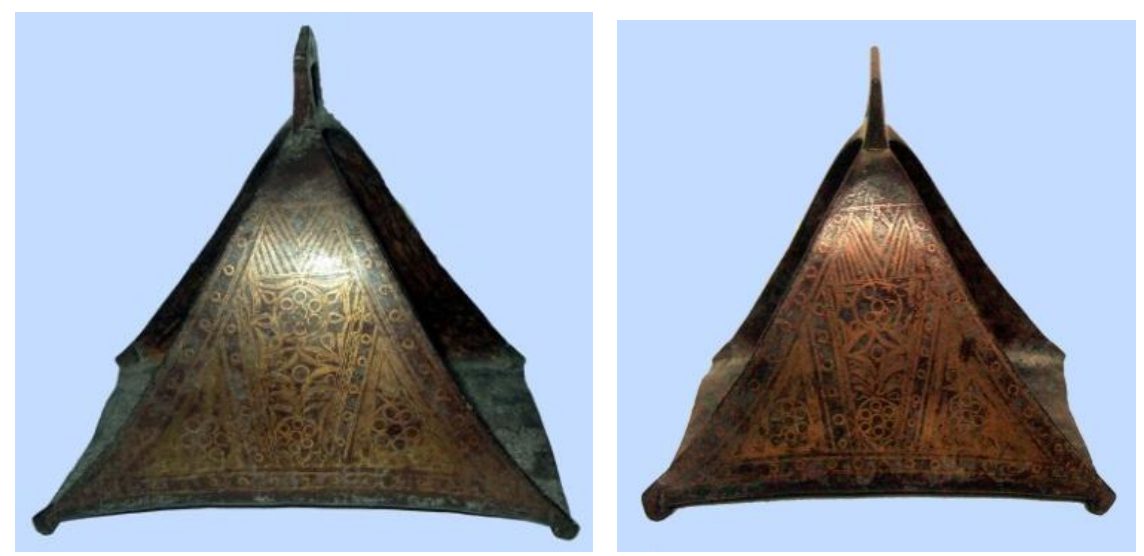

Plate (3) represents two stirrups made of iron, 15.5 X $12.5 \mathrm{~cm}$, register numbers 581 - 582, unpublished. 


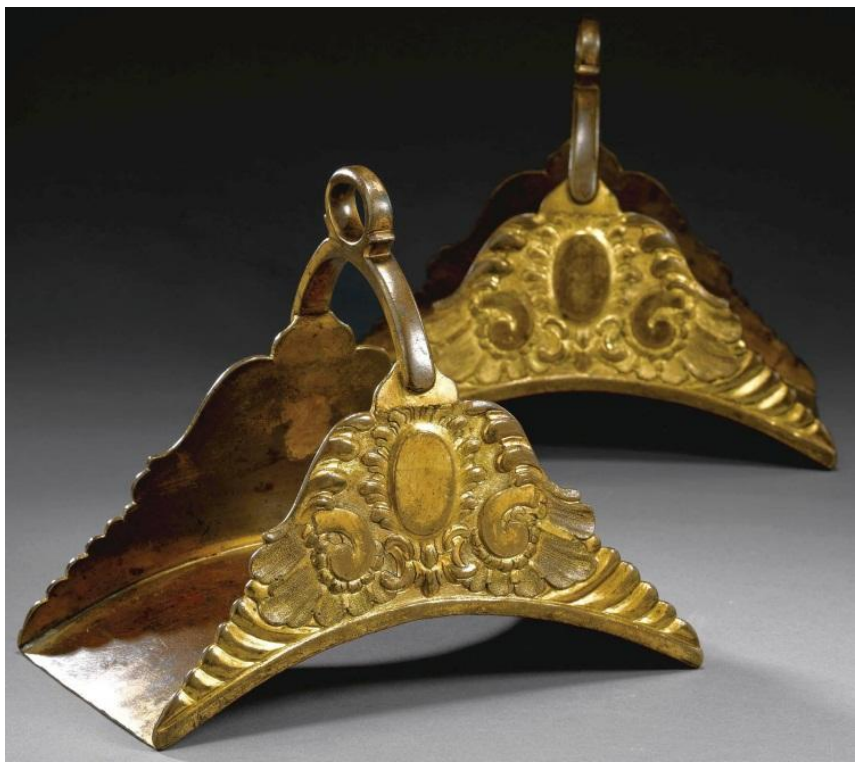

Plate (4) represents two stirrups, Ottoman period, (13AH-19AD)

Special collection about,https://s-media-cache-

ak0.pinimg.com/originals/4e/10/c3/4e10c3d01aceef07f73fb439451c3994.jpg

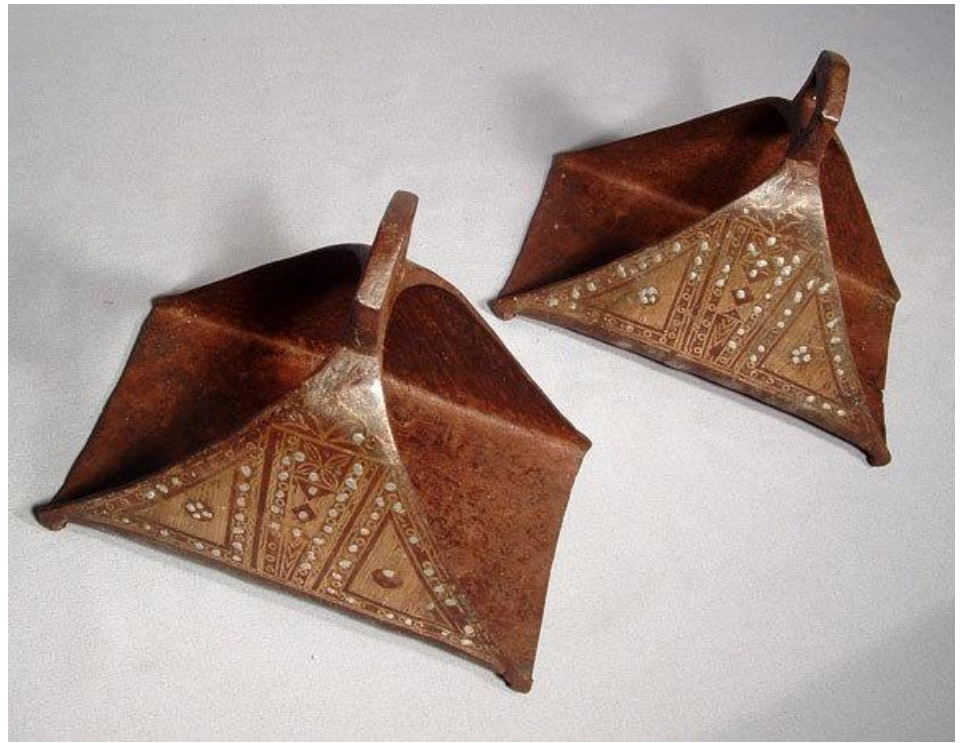

Plate (5) represents two stirrups, Ottoman period, (13AH-19AD) Special collection, httpswww.pinterest.compin402720391664489896 

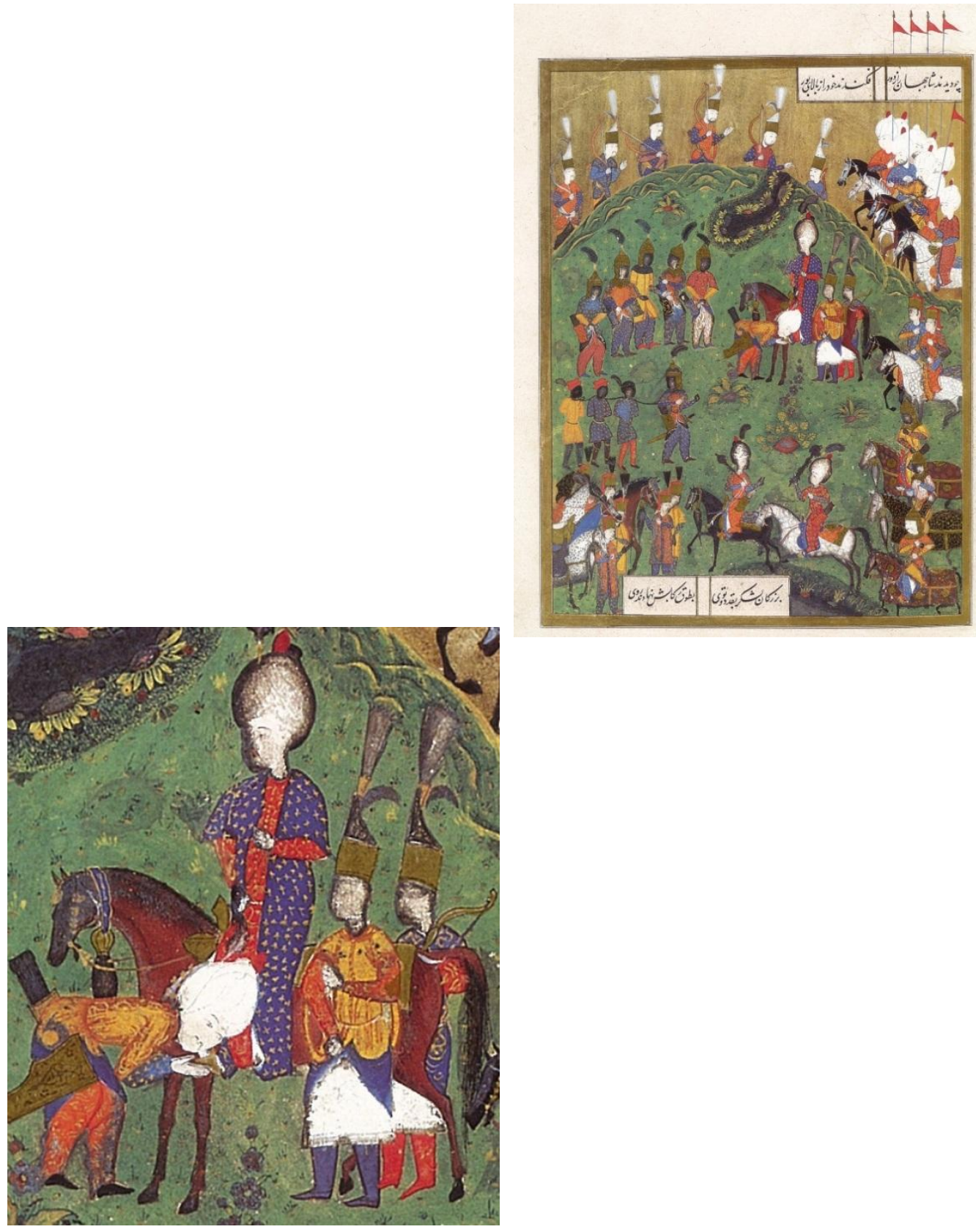

Plate (4) represents a miniature of the arrival of Sultan Suleyman Al Qanony at Bogurdelen, From the manuscript of Suleiman Nama, dated (966 A.H. / 1558 A.D.), and preserved in the Museum of Tobkapu Sarai in Istanbul, about Atil.E, Suleymanname, Pl.7 

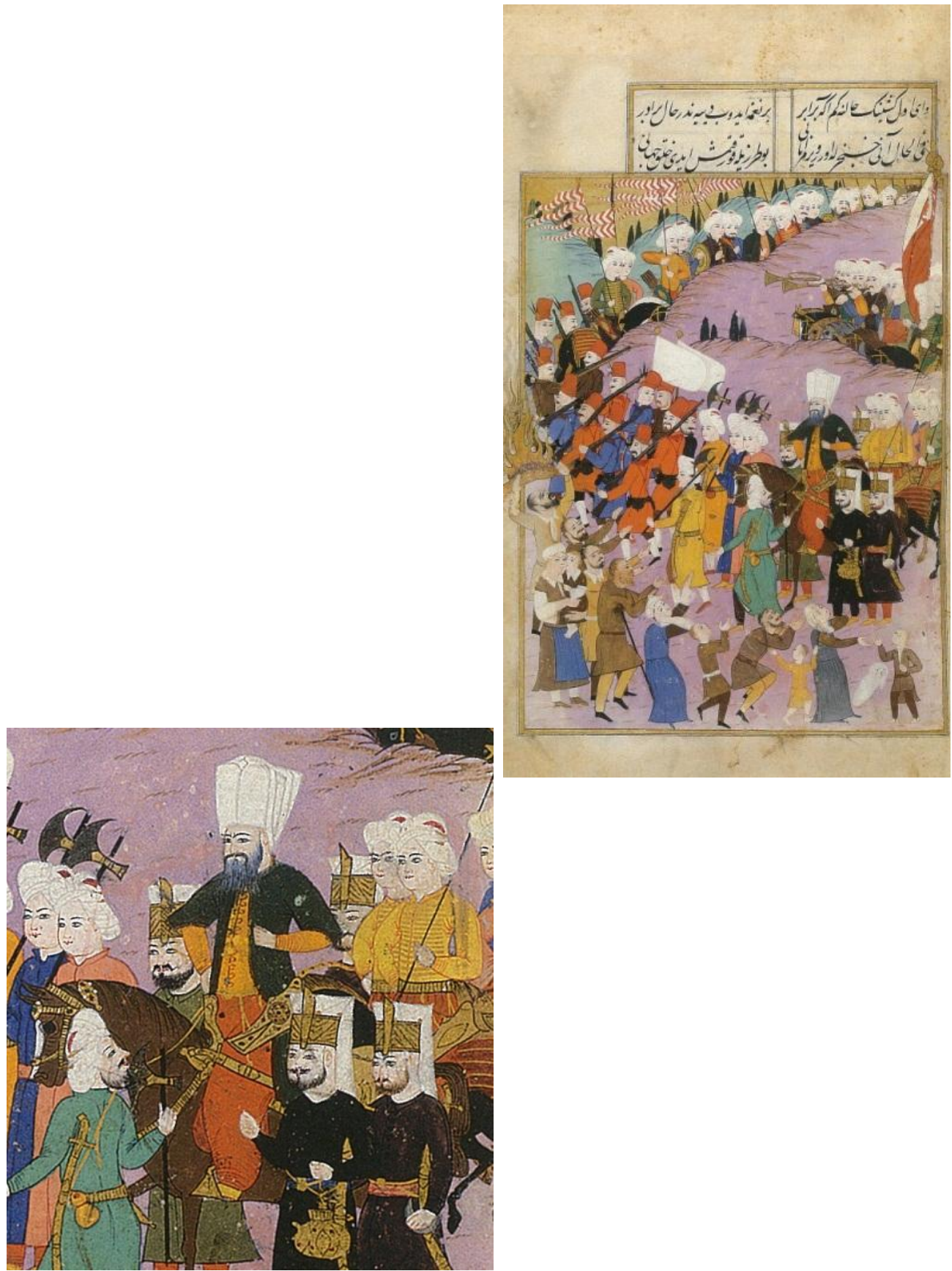

Plate (5) represents a miniature of Kanan Pasha, and his armies from an album dated 1040 A.H. / 1630 A.D., preserved in Istanbul's Tuppakabu Sarai Museum, about Atil.E, Suleymanname, Pl. 186 
نشر ودراسة لمجموعة من الرُكْب محفوظة فى متحف جاير أندرسون بالقاهرة مع أمعائ مقارنتها بنماذج من تصاوير المخطوطات فئن العثمانية

د. أمين عبدالله رشيدى

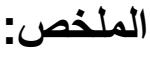

تتتاول هذه الدراسة مجموعة من التحف الفنية تعرف بالرُكب وهى محفوظة

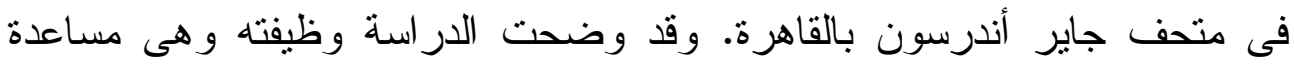

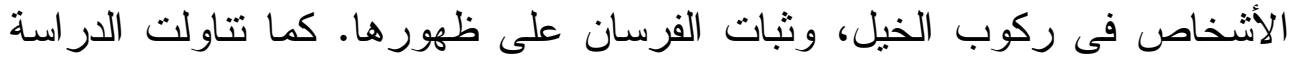

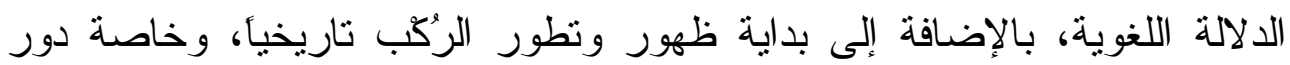

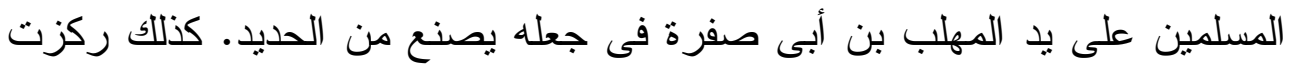

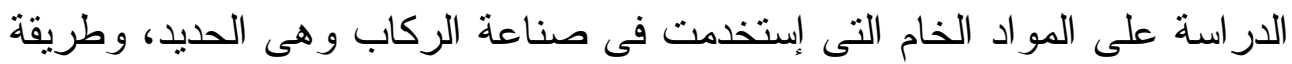

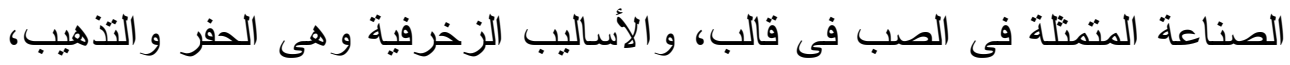

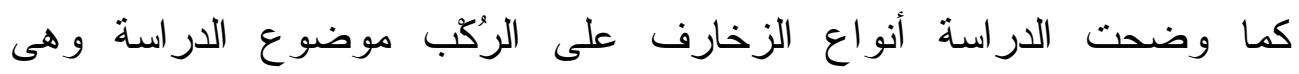

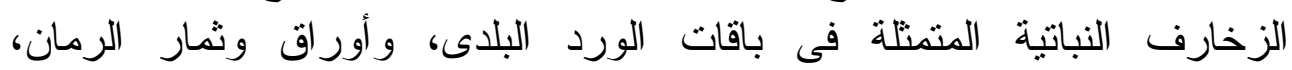

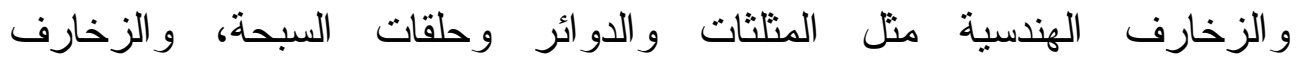

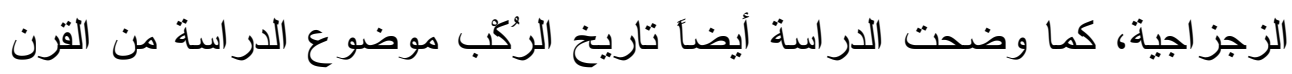

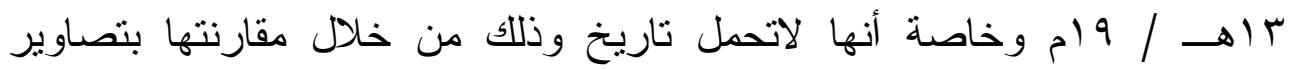

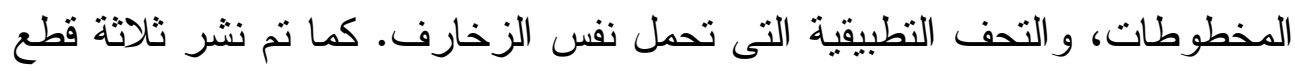

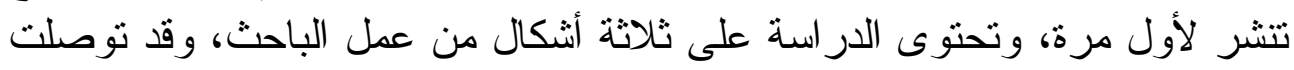
الدر اسة إلى ستة نتائج جديدة فى مجال الفنون الإلى الإنلامية.

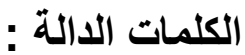

الرُكب - الخيل - الحديد - الصب فى قالب - الحفر - التذهيب - باقات الورد -

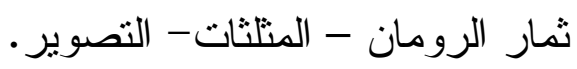

• أستاذ الآثار والفنون الإسلامية المساعد بكلية الآثار- جامعة الفيوم aar01@fayoum.edu.eg 